\title{
Standardization of in-vitro Callus Induction and Regeneration Protocol for Mature Embryo of Proso Millet (Panicum miliaceum L.)
}

\author{
Bankar Ashish Haridas* and Gadakh Santosh Ashok \\ Department of Agricultural Botany, Dr. B.S.K.K.V., Dapoli-415412, India \\ *Corresponding author
}

\author{
A B S T R A C T
}

\begin{tabular}{l} 
Ke y w or d s \\
Mature embryo, \\
MS medium, \\
Callus induction, \\
In vitro \\
regeneration. \\
Article Info \\
Accepted: \\
20 March 2017 \\
Available Online: \\
10 April 2017 \\
\hline
\end{tabular}

The study was conducted to standardize an efficient protocol for callus induction, subsequent growth and in-vitro regeneration in six genotypes of proso millet viz., Gavhe, Sakhroli, Kalsuli, Vari No.10, Asond and Sukdhar. The seeds were surface sterilized with $70 \%$ ethanol for 1 minute $+1 \% \mathrm{HgCl}_{2}$ for 10 minutes recorded maximum aseptic culture establishment in all genotypes. The mature embryo (seeds) of proso millet was cultured on MS medium supplemented with varying concentrations of 2,4-D (0.1-2.0 mg/l) and NAA (1.0-4.0 mg/l) NAA for callus induction for their callus induction and subsequent growth. Maximum frequency of callus induction was observed on MS media supplemented with 2 $\mathrm{mg} / \mathrm{l}$ 2,4-D + $0.5 \mathrm{mg} / \mathrm{l}$ BAP. MS media supplemented with 2, 4-D produced friable, white and yellow colour calli while, in the same media supplemented with NAA produced loose light yellow and loose white colour calli. Maximum shoot regeneration was achieved by transferring calli on MS media supplemented with $4 \mathrm{mg} / \mathrm{l} \mathrm{BAP}$ and $4 \mathrm{mg} / \mathrm{l} \mathrm{Kinetin.} \mathrm{These}$ regenerated plantlets were significantly showed rooting, when transferred on full strength MS supplemented with $0.2 \mathrm{mg} / \mathrm{l} \mathrm{IBA}+0.1 \mathrm{mg} / \mathrm{l} \mathrm{BAP}$ and $2 \%$ sucrose. The rooted plantlet was hardened and transferred to soil.

\section{Introduction}

Proso millet (Panicum miliaceum L.) is cereal plant also known as common millet or vari or hog millet cultivated for its grain mostly in Asia and North America. It is warm season grass with short growing season and low moisture requirement that is capable of producing food where other grains crops would fail. Proso millet is of ancient cultivation and probably domesticated in Central and Eastern Asia. The seeds are small (2-3 mm) and can be cream, yellow, orangered or brown in colour.

Proso millet could be well exploited for biofortification of tribal, the society where maximum malnutrition and under nutrition noticed because of its high nutritional value. Each 100 grams of Proso millet contains large proportion of carbohydrate $(73 \mathrm{~g})$ and thus provides bulk of energy in diets $(378 \mathrm{kcal})$. It also contains fat $(4.2 \mathrm{~g})$, protein $(11 \mathrm{~g})$ and dietary fibre $(8.5 \mathrm{~g})$. Apart from the major nutrients, each 100 grams of Proso millet consist of calcium ( $8 \mathrm{mg}$ ), magnesium (114mg), phosphorous (285mg), iron (3.0mg) etc. The essential amino-acid composition per 100 grams of edible portion is tryptophan (119mg), methionine (221 mg), leucine (1400 $\mathrm{mg}$ ) and isoleucine (465 $\mathrm{mg}$ ) (Anonymous 2013). The grains are gluten free so widely 
used for making beer, brandy and feed for animals, including pigs, fowls and cage-birds. Starch from the grains has been used for sizing textiles (Kaume, 2006).

Seeds of Proso millet are used as a demulcent, treatment for abscesses and boils. Stems and root decoctions are taken against hematuria. Proso millet protein may be useful as a preventive food for certain types of hepatitis. In spite of these added advantages this crop is overlooked because of its low productivity and non-availability of better genotypes. Local genotypes are poor yielders, having narrow genetic base and less variability. Attempt on improvement of proso millet is so far restricted to selection only due to its complicated floral biology.

Tissue culture approach has been proved effective gaining phenotypic variation in regenerated plants such as shorter plants and increased number of tillers (Kavikishor et al., 1992). In-vitro regeneration of proso millet is possible on Murashige and Skoog medium, using mature embryos, immature embryos and immature inflorescence (Jain et al., 2001). Hence, there is enormous scope for achieving improved cultivars of proso millet with good value addition through tissue culture. Keeping this in view the study was conducted with six to standardize callus induction and in-vitro plantlet regeneration protocol through mature embryo as a source of explants and development of somaclones with variable characters.

\section{Materials and Methods}

Seeds of six genotypes of Proso millet viz., Asond, Gavhe, Sukdhar, Sakhroli, Vari No.10 and Kalsuli were used as experimental plant material and collected from Department of Agricultural Botany, Dr. BSKKV, Dapoli. Mature embryos were used as explants for invitro callus induction and regeneration. The experiment was conducted under proper aseptic condition at Plant Biotechnology Centre, Dr. BSKKV., Dapoli, DistrictRatnagiri (MH).

The seeds were surface sterilized by 0.1 per cent Teepol for 10 minutes followed by several times washing under running tap water. After that, seeds were deepen in $(70 \%)$ ethanol for 1-2 minutes and further immersed in (1\%) mercuric chloride for 15 minute. Then these seeds were followed by 2-3 washings with double distilled water and seeds were soaked for 5-6 hours in double distilled water followed by then inoculated on callus induction media and observation recorded on percent aseptic culture establishment. Murashige and Skoog (MS) medium with various concentration of 2, 4-D, NAA, BAP, Kinetin and IBA were used for callus induction. Observation were recorded on Days required to callus initiation, Callus induction response (\%), Weight of callus after 4 weeks (mg) and Nature of callus in terms of colour and texture.

For plantlet regeneration mature embryo derived calli transferring onto fresh MS media supplemented with various concentrations of BAP and Kinetin. Observation were recorded on Regeneration response (\%), Days to shooting and Number of shoots per plant. After development of multiple shoots, the plantlets were separated from each other and transferred to the rooting media for further root development and recorded Days to rooting and Number of roots per plantlet.

Plantlets with well established root systems were washed by double distilled water to remove the entire residual agar medium around the roots. The root portions were dipped in antifungal solution $0.1 \%(\mathrm{w} / \mathrm{v})$ Bavistin for about 5-10 minutes to check the chances of fungal contamination in soil. These rooted seedlings were transplanted to 
the different potting mixture contains soil, FYM, sand and vermiculite.

The experimental design Factorial Completely Randomized Design was used. Data of explants from different media combinations obtained from similar experiments were pooled. The pooled data was analyzed in SASs (Statistical Analysis System software V. 9.1).

\section{Results and Discussion}

\section{Surface sterilization treatment}

Seeds were used as explants for callus culture is treated with sterilizing agents to inactivate the microbes present on their surfaces and the effect of various surface sterilizing treatment on per cent aseptic culture establishment of Proso millet has been recorded. It is necessary to optimize treatment duration and concentration of sterilizing agents in order to cause minimum tissue death. Out of the various surface sterilization treatments tried, treatment $70 \%$ ethanol for 1 minute $+1.0 \%$ $\mathrm{HgCl}_{2}$ for 10 minutes recorded maximum aseptic culture establishment in Gavhe (94.16\%), while lowest response was recorded by genotype Sukdhar (87.50\%). Similar results are observed by Gupta et al., (2001).

\section{Standardization of callus induction protocol}

\section{Effect of genotype and growth regulator on callus induction}

Callus mediated plantlet regeneration is a complex phenomenon. Genotype can influence both frequency of callus induction and regeneration (Larkin and Scowcroft, 1981). Therefore, the identification of genotype superior for callus induction and callus mediated regeneration is important. The significant differences were observed between the genotypes for callus induction response (Table 1$)$.

The maximum callus induction response was recorded on MS media in Gavhe (37.07\%), while, the minimum callus induction response was observed in kalsuli (31.66\%). These results are in accordance with Cummings et al., (1976).

The maximum callus induction response was observed in $2 \mathrm{mg} / \mathrm{l}$ 2, 4-D concentration $(63.67 \%)$ followed by $1 \mathrm{mg} / \mathrm{l} 2$, 4-D concentration $(46.94 \%)$ and $0.5 \mathrm{mg} / 1$ 2, 4-D concentration $(20.56 \%)$ in all genotypes. Gavhe showed highest callus induction $(81.67 \%)$ in $2 \mathrm{mg} / \mathrm{l}$ 2,4-D concentration whereas; lower response $(20.00 \%)$ was recorded in genotype Asond, Gavhe, Sakhroli, and Vari no.10 in $0.5 \mathrm{mg} / 1$ 2,4-D. No response for callusing was recorded when MS media supplemented with $0.1 \mathrm{mg} / 1$ 2, 4-D (Table 1). Patil et al., (2009) and Anirudha et al., (2012) recorded response of genotype for callus induction and plantlet regeneration and effect of media on somatic embryogenesis and plant differentiation in media supplemented with 2 , 4-D. White friable and hard creamy embryogenic calli were observed among the six genotypes in these media (Plate II). Characteristics of callus in terms of its colour and appearance play an important role in determining regeneration (Mohanty et al., 1985)

Similarly, maximum callus induction response was recorded in 3mg/l NAA (38.33\%) followed by $4 \mathrm{mg} / \mathrm{l}$ NAA $(37.10 \%)$ and $2 \mathrm{mg} / \mathrm{l}$ NAA (30.77\%). The lowest (27.77\%) response for callusing was recorded by $1 \mathrm{mg} / \mathrm{l}$ NAA (Table 1). Loose white and loose light yellow colour calli were observed in all genotypes (Plate II). The similar types of results are obtained by Kavikishor et al., (1992) and Patil et al., (2009). 
Effect of genotype on days to callus induction

Differences were observed in between the genotype for days to callus induction (Fig. 1). Among the six genotypes minimum mean number of days required for callus initiation recorded by genotype Gavhe (5.42 days) and maximum number of days required for callus induction recorded by genotype Kalsuli (8.11days). Similar observations were recorded by Patil et al., (2009) in finger millet.

\section{Effect of genotype and growth regulators on weight of callus}

The differential response was observed for weight of callus in all genotypes (Table 2). The mean values for weight of callus were found highest $(51.15 \mathrm{mg})$ in genotype Gavhe. While lowest (28.88mg) in genotype Kalsuli.

Highest callus weight with mature embryo explants was observed in MS media supplemented with $2 \mathrm{mg} / 1$ 2,4-D (84.02mg) while, lowest callus weight $(19.01 \mathrm{mg})$ with $0.5 \mathrm{mg} / \mathrm{l}$ 2,4-D.2,4-D concentration of $0.1 \mathrm{mg} / \mathrm{l}$ failed to show callusing. Similarly, $4 \mathrm{mg} / \mathrm{l}$ NAA had given maximum $(67.11 \mathrm{mg})$ callus weight whereas; minimum $(22.01 \mathrm{mg})$ was recorded in $2 \mathrm{mg} / 1 \mathrm{NAA}$.

\section{Standardization of regeneration protocol}

The proliferated calli were transferred on MS medium supplemented with different concentration of growth regulators (cytokinin) for regeneration.

\section{Effect of genotypes and growth regulator on plantlet regeneration}

Calli of different genotype may require different media and set of conditions for regenerations (Masteller and Holden 1970). The differences were observed between the six genotypes for mean values of plantlet regeneration (Table 3 ). The maximum plantlet regeneration response was recorded by genotype Sakhroli (17.71\%), while minimum response was recorded by Sukdhar (11.46\%).

Presence of required level of hormones is a pre-requiste for the initiation of in-vitro organogenesis and variation in plantlet regeneration response reported due to different concentrations of BAP and Kinetin.

Media containing 4mg/l BAP and Kinetin only showed plantlet regeneration. The highest plantlet regeneration response was recorded in Sakhroli (60.42\%) while, lowest plantlet regeneration response $(31.26 \%)$ was observed in Sukdhar in media enriched with BAP. Similarly, the highest plantlet regeneration response (47.92\%) was recorded in Asond while, lowest plantlet regeneration response $(27.09 \%)$ was recorded in Vari No.10 in media containing Kinetin. (Plate III). Similar types of results were obtained by Kuar and Kothari (2004) and Jha et al., (2009).

\section{Effect of growth regulators on days to plantlet regeneration}

Medium containing BAP showed earlier regeneration while, delayed regeneration observed in medium containing Kinetin (Fig. 2 ). The media containing $4 \mathrm{mg} / \mathrm{l}$ BAP and $4 \mathrm{mg} / \mathrm{l}$ Kinetin only showed plantlet regeneration out of 3 BAP and 3 Kinetin combinations studied. Among all genotypes minimum days to plantlet regeneration are recorded 4.31 days in Gavhe and maximum 6.69 days in Sukdhar. 
Table.1 Effect of 2,4-D and NAA on callus induction response (\%) from mature embryo on MS medium

\begin{tabular}{|c|c|c|c|c|c|c|c|c|c|c|}
\hline \multirow{3}{*}{$\begin{array}{c}\text { Sr. } \\
\text { No. }\end{array}$} & Genotypes & \multicolumn{10}{|c|}{ MS } \\
\cline { 3 - 10 } & & \multicolumn{9}{|c|}{$\mathbf{2 , 4 - D} \mathbf{~ m g / l}$} \\
\cline { 3 - 10 } & & $\mathbf{0 . 1}$ & $\mathbf{0 . 5}$ & $\mathbf{1 . 0 0}$ & $\mathbf{2 . 0 0}$ & $\mathbf{1 . 0 0}$ & $\mathbf{2 . 0 0}$ & $\mathbf{3 . 0 0}$ & $\mathbf{4 . 0 0}$ & Mean \\
\hline 1 & Asond & 0.00 & 20.00 & 51.66 & 75.00 & 25.00 & 28.33 & 35.00 & 41.66 & 34.58 \\
& & $(0.00)$ & $(26.45)$ & $(45.96)$ & $(60.07)$ & $(29.74)$ & $(32.02)$ & $(36.24)$ & $(40.20)$ & $(33.83)$ \\
\hline 2 & Gavhe & 0.00 & 20.00 & 56.66 & 81.67 & 26.66 & 36.66 & 36.66 & 38.33 & 37.07 \\
& & $(0.00)$ & $(26.45)$ & $(48.85)$ & $(64.69)$ & $(30.76)$ & $(37.26)$ & $(37.26)$ & $(38.22)$ & $(35.44)$ \\
\hline 3 & Sukdhar & 0.00 & 21.66 & 40.00 & 58.33 & 31.66 & 23.33 & 45.00 & 33.33 & 31.66 \\
& & $(0.00)$ & $(27.60)$ & $(39.21)$ & $(49.80)$ & $(34.23)$ & $(28.86)$ & $(42.12)$ & $(35.22)$ & $(32.13)$ \\
\hline 4 & Sakhroli & 0.00 & 20.00 & 48.33 & 55.33 & 23.33 & 38.33 & 36.66 & 35.00 & 32.12 \\
& & $(0.00)$ & $(26.45)$ & $(44.04)$ & $(47.88)$ & $(28.67)$ & $(38.24)$ & $(37.20)$ & $(36.24)$ & $(32.34)$ \\
\hline 5 & Vari No.10 & 0.00 & 20.00 & 45.00 & 53.33 & 28.33 & 35.00 & 31.66 & 41.00 & 31.79 \\
& & $(0.00)$ & $(26.45)$ & $(42.12)$ & $(46.92)$ & $(31.74)$ & $(36.27)$ & $(34.23)$ & $(40.20)$ & $(32.24)$ \\
\hline 6 & Kalsuli & 0.00 & 21.66 & 40.00 & 58.33 & 31.66 & 23.00 & 45.00 & 33.33 & 31.62 \\
& & $(0.00)$ & $(27.60)$ & $(39.21)$ & $(49.80)$ & $(34.23)$ & $(28.86)$ & $(42.12)$ & $(35.22)$ & $(32.13)$ \\
\hline & Mean & 0.00 & 20.56 & 46.94 & 63.67 & 27.78 & 30.78 & 38.33 & 37.10 & 33.14 \\
& & $(0.00)$ & $(26.83)$ & $(43.23)$ & $(53.20)$ & $(31.56)$ & $(33.58)$ & $(38.20)$ & $(37.55)$ & $(33.02)$ \\
& & & & & & & & & & \\
\hline
\end{tabular}

Figures in parentheses indicate arcsine transformed value

\begin{tabular}{|c|c|c|c|}
\hline & Genotype & Auxin & Genotype X Auxin \\
\hline SEm & 0.57 & 0.66 & 1.63 \\
\hline C.D. at $1 \%$ & 2.13 & 2.46 & 6.03 \\
\hline
\end{tabular}

Table.2 Effect of 2,4-D and NAA on weight of callus after 4 weeks derived from mature embryo on MS medium

\begin{tabular}{|c|c|c|c|c|c|c|c|c|c|c|}
\hline \multirow{3}{*}{$\begin{array}{c}\text { Sr. } \\
\text { No } \\
\text {. }\end{array}$} & \multirow[t]{3}{*}{ Genotypes } & \multicolumn{9}{|c|}{ MS } \\
\hline & & \multicolumn{4}{|c|}{ 2,4-D mg/l } & \multicolumn{5}{|c|}{ NAA mg/l } \\
\hline & & 0.1 & 0.5 & 1.00 & 2.00 & 1.00 & 2.00 & 3.00 & 4.00 & Mean \\
\hline 1 & Asond & 0.00 & 41.36 & 55.62 & 71.11 & 42.15 & 49.57 & 52.71 & 67.11 & 49.30 \\
\hline 2 & Gavhe & 0.00 & 43.44 & 72.23 & 84.02 & 38.67 & 48.65 & 68.96 & 73.33 & 51.15 \\
\hline 3 & Sukdhar & 0.00 & 25.33 & 40.51 & 54.17 & 28.72 & 39.96 & 40.95 & 32.36 & 33.23 \\
\hline 4 & Sakhroli & 0.00 & 19.01 & 42.64 & 64.20 & 23.91 & 21.01 & 38.53 & 42.04 & 28.88 \\
\hline 5 & Vari No.10 & 0.00 & 19.10 & 42.92 & 73.09 & 22.02 & 29.32 & 43.12 & 38.92 & 29.57 \\
\hline \multirow[t]{2}{*}{6} & Kalsuli & 0.00 & 26.12 & 42.47 & 55.19 & 26.58 & 38.36 & 32.47 & 28.82 & 29.89 \\
\hline & Mean & 0.00 & 29.06 & 49.39 & 66.96 & 30.34 & 37.81 & 46.12 & 47.09 & 37.00 \\
\hline
\end{tabular}

\begin{tabular}{|c|c|c|c|}
\hline & Genotype & Auxin & Genotype X Auxin \\
\hline SEm & 0.65 & 0.76 & 1.86 \\
\hline C.D. at $1 \%$ & 1.85 & 2.13 & 5.23 \\
\hline
\end{tabular}


Table.3 Effect of BAP and Kinetin (mg/l) on regeneration response (\%) from mature embryo derived calli

\begin{tabular}{|c|c|c|c|c|c|c|c|c|}
\hline \multirow{2}{*}{$\begin{array}{c}\text { Sr. } \\
\text { No. }\end{array}$} & \multirow{2}{*}{ Genotypes } & \multicolumn{6}{|c|}{ Mature Embryo } & \multirow{2}{*}{ Mean } \\
\cline { 3 - 8 } & & \multicolumn{3}{|c|}{ BAP mg/l } & \multicolumn{3}{c|}{ Kinetin mg/l } & \\
\cline { 3 - 8 } $\mathbf{1}$ & & $\mathbf{1}$ & $\mathbf{2}$ & $\mathbf{4}$ & $\mathbf{1}$ & $\mathbf{2}$ & $\mathbf{4}$ & \\
\hline & & 0.00 & 0.00 & 56.25 & 0.00 & 0.00 & 47.92 & 17.36 \\
& & $(0.00)$ & $(0.00)$ & $(48.80)$ & $(0.00)$ & $(0.00)$ & $(43.80)$ & $(15.43)$ \\
\hline $\mathbf{2}$ & Gavhe & 0.00 & 0.00 & 56.06 & 0.00 & 0.00 & 41.66 & 16.31 \\
& & $(0.00)$ & $(0.00)$ & $(48.61)$ & $(0.00)$ & $(0.00)$ & $(40.00)$ & $(14.77)$ \\
\hline $\mathbf{3}$ & Sukdhar & 0.00 & 0.00 & 31.26 & 0.00 & 0.00 & 37.50 & 11.45 \\
& & $(0.00)$ & $(0.00)$ & $(33.92)$ & $(0.00)$ & $(0.00)$ & $(37.59)$ & $(11.32)$ \\
\hline $\mathbf{4}$ & Sakhroli & 0.00 & 0.00 & 60.42 & 0.00 & 0.00 & 45.83 & 17.70 \\
& & $(0.00)$ & $(0.00)$ & $(51.20)$ & $(0.00)$ & $(0.00)$ & $(42.59)$ & $(15.63)$ \\
\hline $\mathbf{5}$ & Vari No.10 & 0.00 & 0.00 & 58.33 & 0.00 & 0.00 & 27.09 & 14.23 \\
& & $(0.00)$ & $(0.00)$ & $(50.00)$ & $(0.00)$ & $(0.00)$ & $(31.14)$ & $(13.52)$ \\
\hline $\mathbf{6}$ & Kalsuli & 0.00 & 0.00 & 39.58 & 0.00 & 0.00 & 45.83 & 14.23 \\
& & $(0.00)$ & $(0.00)$ & $(38.80)$ & $(0.00)$ & $(0.00)$ & $(42.61)$ & $(13.57)$ \\
\hline & Mean & 0.00 & 0.00 & 50.34 & 0.00 & 0.00 & 40.96 & 15.21 \\
& & $(0.00)$ & $(0.00)$ & $(45.22)$ & $(0.00)$ & $(0.00)$ & $(39.62)$ & $(14.14)$ \\
\hline
\end{tabular}

(Figures in parentheses indicate arcsine transformed value)

\begin{tabular}{|c|c|c|c|}
\hline & Genotype & Cytokinin & Genotype X Cytokinin \\
\hline SEm & 0.83 & 0.83 & 2.03 \\
\hline C. D. at $1 \%$ & 3.09 & 3.09 & 7.58 \\
\hline
\end{tabular}

Table.4 Effect of BAP and Kinetin (mg/l) on number of plantlets regenerated per callus

\begin{tabular}{|c|c|c|c|c|c|c|c|c|c|c|}
\hline \multirow{3}{*}{$\begin{array}{l}\text { Sr. } \\
\text { No. }\end{array}$} & \multirow[t]{3}{*}{ Genotypes } & \multicolumn{8}{|c|}{ No. of plantlets regenerated per callus } & \multirow[t]{3}{*}{ Mean } \\
\hline & & \multicolumn{4}{|c|}{ BAP (mg/l) } & \multicolumn{4}{|c|}{ Kinetin (mg/l) } & \\
\hline & & 1 & 2 & 4 & Mean & 1 & 2 & 4 & Mean & \\
\hline 1 & Asond & 0.00 & 0.00 & 6.50 & 2.16 & 0.00 & 0.00 & 5.75 & 1.91 & 2.04 \\
\hline 2 & Gavhe & 0.00 & 0.00 & 8.59 & 1.86 & 0.00 & 0.00 & 7.92 & 2.63 & 2.74 \\
\hline 3 & Sukdhar & 0.00 & 0.00 & 2.90 & 0.97 & 0.00 & 0.00 & 2.67 & 0.88 & 0.92 \\
\hline 4 & Sakhroli & 0.00 & 0.00 & 6.33 & 2.11 & 0.00 & 0.00 & 5.75 & 1.91 & 2.01 \\
\hline 5 & Vari No.10 & 0.00 & 0.00 & 4.66 & 1.55 & 0.00 & 0.00 & 4.33 & 1.44 & 1.49 \\
\hline \multirow[t]{2}{*}{6} & Kalsuli & 0.00 & 0.00 & 5.50 & 1.83 & 0.00 & 0.00 & 5.08 & 1.69 & 1.76 \\
\hline & Mean & 0.00 & 0.00 & 5.74 & 1.91 & 0.00 & 0.00 & 5.24 & 1.74 & 1.83 \\
\hline
\end{tabular}

\begin{tabular}{|c|c|c|c|}
\hline & Genotype & Cytokinin & Genotype X Cytokinin \\
\hline SEm & 0.07 & 0.07 & 0.19 \\
\hline C.D. at $1 \%$ & 0.22 & 0.22 & 0.54 \\
\hline
\end{tabular}


Table.5 Effect of IBA and NAA on root induction per plantlet in shoots regenerated from Calli

\begin{tabular}{|c|c|c|c|c|c|c|c|c|c|c|}
\hline \multirow{3}{*}{$\begin{array}{l}\text { Sr. } \\
\text { No }\end{array}$} & \multirow[t]{3}{*}{ Genotypes } & \multicolumn{8}{|c|}{ No. of roots per plantlet } & \multirow[t]{3}{*}{ Mean } \\
\hline & & \multicolumn{4}{|c|}{ IBA mg/l } & \multicolumn{4}{|c|}{ NAA mg/l } & \\
\hline & & $\mathrm{R}_{1}$ & $\mathrm{R}_{2}$ & $\mathrm{R}_{3}$ & Mean & $\mathrm{R}_{4}$ & $\mathrm{R}_{5}$ & $\mathrm{R}_{6}$ & Mean & \\
\hline 1 & & 7.41 & 10.83 & 5.50 & & 4.41 & 9.91 & 7.00 & 0 & 7.51 \\
\hline 2 & & 5.3 & 11 & 3.41 & & 2.75 & & 3.5 & 7 & 36 \\
\hline 3 & & 41 & 9.66 & 3.83 & 5.96 & 8 & 7. & 4.66 & 4.77 & 5. \\
\hline 4 & $\mathrm{hr}$ & 7.33 & 10.16 & 4.75 & 7.41 & 3.25 & 7.41 & 3.83 & 4.83 & 6.12 \\
\hline 5 & Vari No.10 & 3.83 & 8.58 & 4.00 & 5.47 & 2.58 & 5.75 & 3.08 & 3.80 & 4.63 \\
\hline \multirow[t]{2}{*}{6} & $\mathrm{~K}$ & 5.00 & 8.08 & 2.58 & 5.22 & 3.50 & 6.08 & 3.16 & 4.24 & 4.73 \\
\hline & Mean & 5.55 & 9.56 & 4.01 & 6.37 & 3.17 & 7.21 & 4.21 & 4.87 & 5.62 \\
\hline
\end{tabular}

\begin{tabular}{|c|c|c|c|}
\hline & Genotype & Auxin & Genotype X Auxin \\
\hline SEm & 0.20 & 0.20 & 0.49 \\
\hline C.D. at $1 \%$ & 0.75 & 0.75 & 1.84 \\
\hline
\end{tabular}

$\mathrm{R}_{1}: 1 / 2 \mathrm{MS}+0.1 \mathrm{mg} / 1 \mathrm{IBA}+0.1 \mathrm{mg} / \mathrm{BAP}+3 \%$ sucrose. $\quad \mathrm{R}_{2}: \mathrm{MS}+0.2 \mathrm{mg} / \mathrm{lBA}+0.1 \mathrm{mg} / \mathrm{l} \mathrm{BAP}+2 \%$ sucrose.

$\mathrm{R}_{3}: 1 / 2 \mathrm{MS}+0.1 \mathrm{mg} / \mathrm{l} \mathrm{IBA}+0.1 \mathrm{mg} / \mathrm{l} \mathrm{BAP}+2 \%$ sucrose. $\quad \mathrm{R}_{4}: 1 / 2 \mathrm{MS}+0.5 \mathrm{mg} / \mathrm{l} \mathrm{NAA}+0.2 \mathrm{mg} / \mathrm{l} \mathrm{Kinetin}+3 \%$ sucrose.

$\mathrm{R}_{5}: \mathrm{MS}+2 \mathrm{mg} / \mathrm{l} \mathrm{NAA}+0.2 \mathrm{mg} / \mathrm{l}$ Kinetin $+2 \%$ sucrose. $\quad \mathrm{R}_{6}: \mathrm{MS}+1 \mathrm{mg} / \mathrm{l} \mathrm{NAA}+0.1 \mathrm{mg} / \mathrm{l}$ Kinetin $+3 \%$ sucrose

Fig.1 Genotypic variability in relation to 2,4-D and NAA for days to callus induction

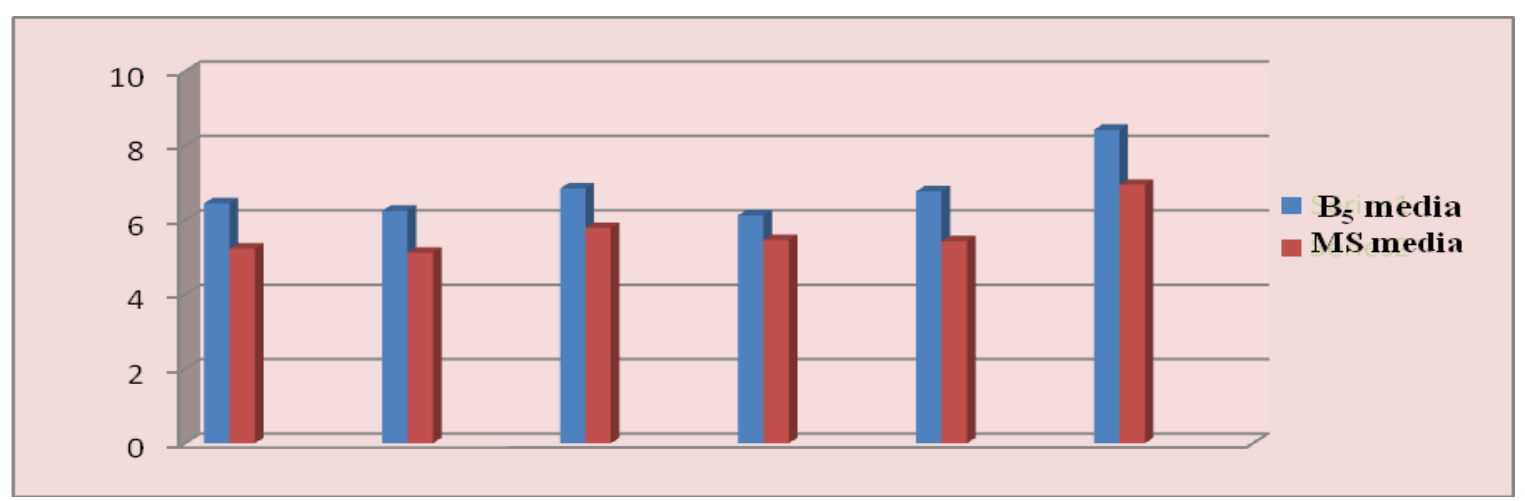

Fig.2 Genotypic variability in relation to BAP and Kinetin (mg/l) for days to plantlet regeneration

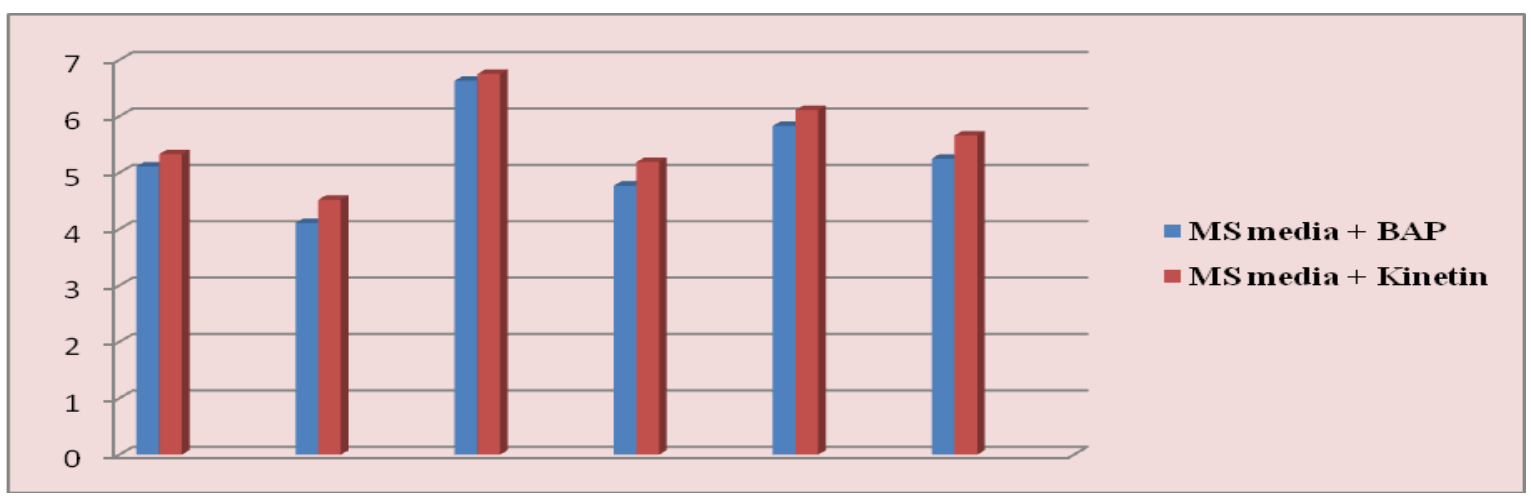


Fig.3 Genotypic variability in relation to IBA and NAA $(\mathrm{mg} / \mathrm{l})$ for days to rooting

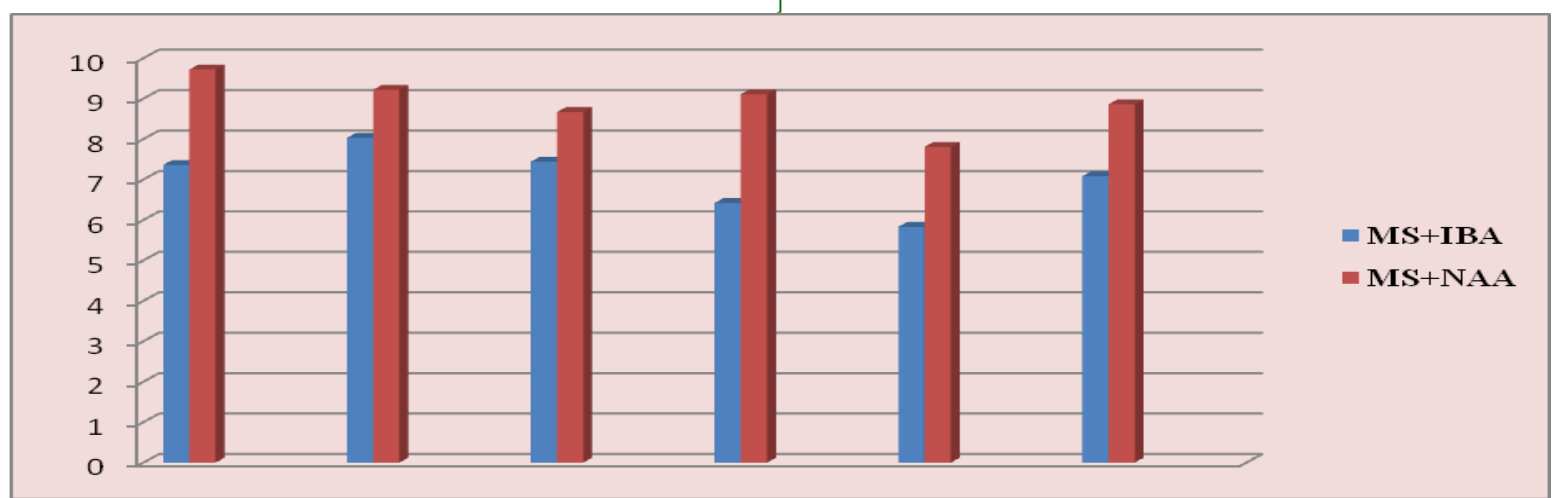

\section{Plate I: Callus initiation in Proso millet}

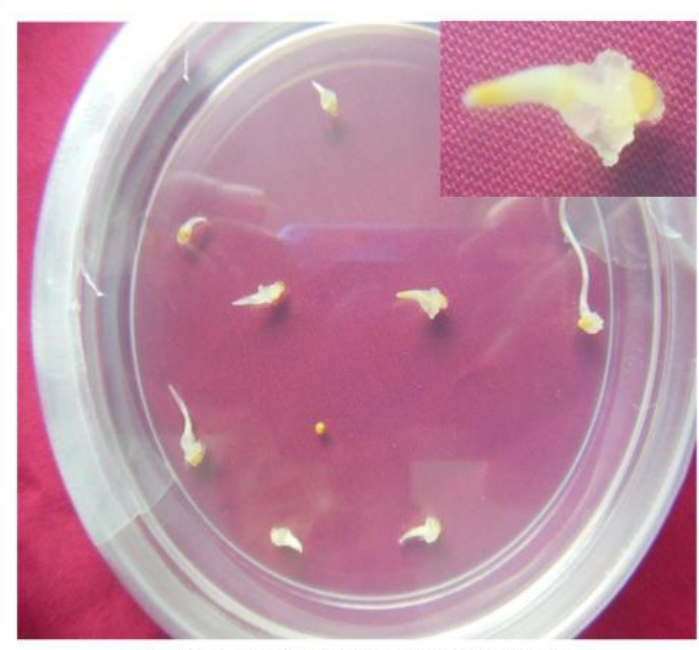

Initiation of callus from mature embryos axes

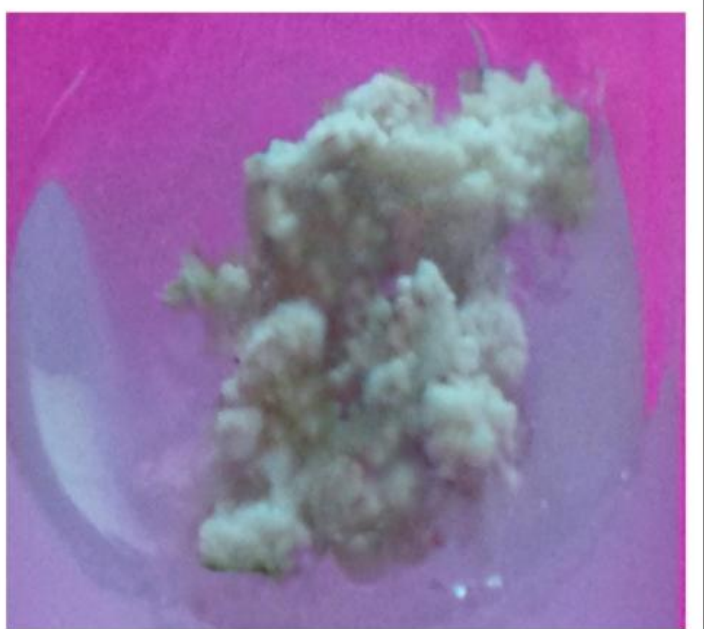

Well organized white friable callus in MS $+2 \mathrm{mg} / 12,4 \mathrm{D}$
Plate II: Nature of callus

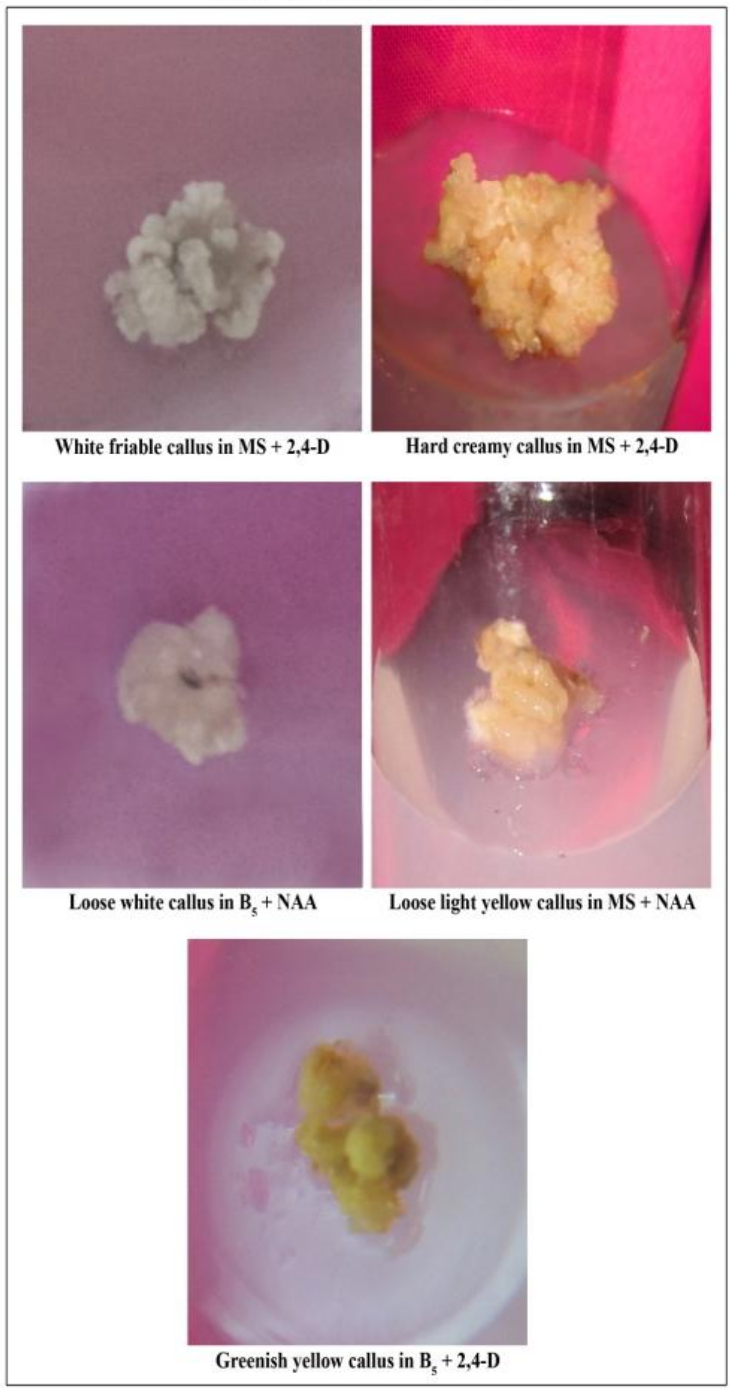




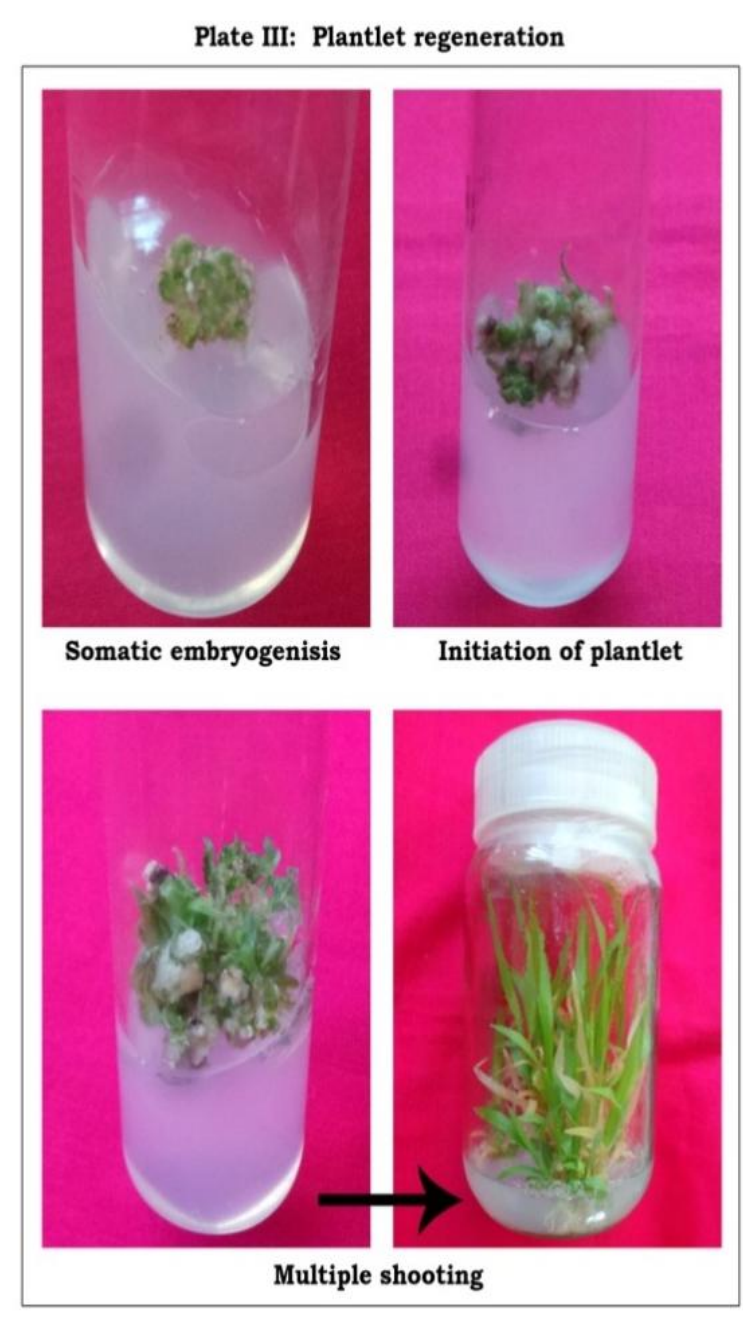

Effect of growth regulators on number of plantlet regenerated per callus

Mature embryo explants tried for different levels of BAP and Kinetin showed variability for plantlets production per callus (Table 4). The highest number of plantlets was recorded by the genotype Gavhe (8.59) in MS media containing $4 \mathrm{mg} / \mathrm{l}$ BAP concentration while, while the least number of plantlets was recorded by genotype Sukdhar (2.90). Similarly, the genotypes Gavhe was recorded maximum (7.92) number of plantlets in MS media supplemented with $4 \mathrm{mg} / \mathrm{l}$ Kinetin concentration while, Sukdhar was recorded minimum (2.67) number of plantlets.
Plant IV: Rooting and hardening

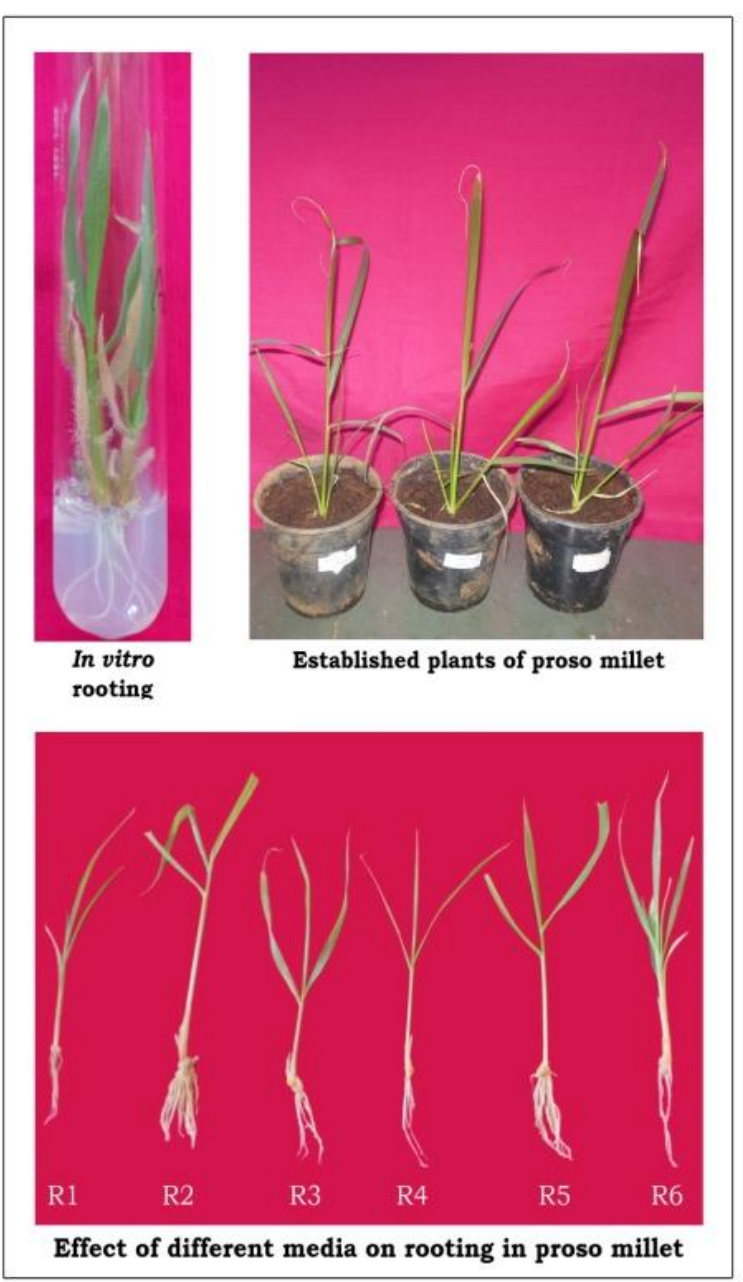

\section{Rooting}

\section{Effect of genotypes and growth regulators on days to rooting}

The variations in response were observed between the genotypes for days required to rooting using different growth regulators (Fig. 3). Genotype Vari No.10 showed earlier rooting (6.82 days) while Gavhe required more days (8.63 days) for rooting irrespective of media combinations. Endogenous auxin Supply and their regulation may play a key role in root initiation; so they are essential for rooting. Minimum mean days (7.02) were required by media contains IBA as compared to NAA (8.89 days). Full MS media 
supplemented with $0.2 \mathrm{mg} / \mathrm{l} \mathrm{IBA}+0.1 \mathrm{mg} / \mathrm{l}$ $\mathrm{BAP}+2 \%$ sucrose observed as the most suitable combination which recorded earlier 5.37 days to rooting followed by $1 / 2 \mathrm{MS}+$ $0.1 \mathrm{IBA}+0.1 \mathrm{mg} / \mathrm{l} \mathrm{BAP}+3 \%$ sucrose $(7.38$ days) and $1 / 2 \mathrm{MS}+0.1 \mathrm{IBA} \mathrm{mg} / \mathrm{l}+0.1 \mathrm{mg} / \mathrm{l}$ BAP $+2 \%$ sucrose (8.31 days). Similarly, full MS media containing $2 \mathrm{mg} / \mathrm{l} \mathrm{NAA}+0.2 \mathrm{mg} / \mathrm{l}$ Kinetin+ $2 \%$ sucrose recorded earlier (7.13 days) rooting followed by $1 \mathrm{mg} / \mathrm{l} \mathrm{NAA}+$ $0.1 \mathrm{mg} / \mathrm{l}$ Kinetin $+3 \%$ sucrose (9.02 days) and $1 / 2 \mathrm{MS}+0.5 \mathrm{mg} / \mathrm{l} \mathrm{Kinetin}+3 \%$ sucrose $(10.52$ days). The results are in conformity of Patil et al., 2009.

\section{Effect of genotypes and growth regulator on Number of roots per plantlets}

Genotype Asond showed maximum mean number of roots (7.51) per plantlets while, Kalsuli showed minimum mean number of roots (4.73) per plantlet (Table 5).

More number of roots was observed in media containing IBA as compared to media containing NAA. The differences were observed in number of roots per plantlets with respect to different levels of auxins is shown in Plate IV. IBA concentration of $0.2 \mathrm{mg} / \mathrm{l}$ yielded maximum (9.56) number of roots followed by (5.55) in $1 / 2 \mathrm{MS}+0.1 \mathrm{mg} / 1 \mathrm{IBA}+$ $0.1 \mathrm{mg} / \mathrm{l} \mathrm{BAP}+3 \%$ sucrose and (4.01) in $1 / 2$ $\mathrm{MS}+0.1 \mathrm{mg} / \mathrm{l} \mathrm{IBA}+0.1 \mathrm{mg} / \mathrm{l} \mathrm{BAP}+2 \%$ sucrose.

Similarly, NAA concentration of $2 \mathrm{mg} / \mathrm{l}$ NAA showed maximum (7.21) roots per plantlets followed by (4.21) in 1mg/l NAA and (3.17) in $1 / 2 \mathrm{MS}+0.5 \mathrm{mg} / 1 \mathrm{NAA}$. Similar results were recorded by Patil et al., (2009).

\section{Hardening and establishment}

The healthy rooted plants were transferred to different potting mixture and assess their effect on per cent survival of Proso millet plantlets. Highest plants survival was recorded in Sakhroli (74.17\%) in $\mathrm{T}_{6}$ treatment i.e. sand + soil + vermiculite in 1:1:1 proportion, while lower percentage of survival was observed in Sukdhar (17.90\%). Similar type of results is also recorded by Patil et al., (2009).

In conclusion callus can be initiated in all six genotypes through mature embryo as a source of explants on MS media supplemented with 2,4-D and NAA. Callus induction response was found better on MS media containing 2,4-D $(2 \mathrm{mg} / \mathrm{l})$. Significant regeneration of plantlets could be obtained in all six genotypes using embryogenic calli on MS media containing 4mg/l BAP and Kinetin. A considerable range of variation was observed for callus induction response (\%), days to callus induction, weight of callus after 4 week and nature of callus, plantlet regeneration response (\%), number of days required to first plantlet regeneration, number of plantlets per callus and days to rooting and number of roots per plantlet. The callus induction and regeneration ability was determined by genotype, media and growth regulators combinations in the medium. The presence of variability for callus induction and plantlet regeneration offers a great scope for selecting most suitable genotypes for creating somaclonal variation in Proso millet.

\section{References}

Anirudha, Subhash and Sonam. 2012. In-vitro regeneration of pearl millet from mature embryo derived callus Int. J. Agril. Sci. Res., 2(4): 37-40

Anonymous. 2013. Source: Millet Network of India. http://www.milletindia.org

Cummings, D.P., C.E. Green and Stuthman, D.D. 1976. Callus induction and plantlet regeneration in Oats. Crop Sci., 16: 465-470

Gupta, P., S. Raghuwanshi and Tyagi, A.K. 2001. Assessment of the efficiency of various Gene promoters via Biolistics in 
leaf and regenerating seed callus of millets (Eleusine coracana) and (Echinochloa crusgalli). Plant Biotechnol., 18(4): 275-282.

Jha, P., C.B. Yadav, V. Anjaiah and Bhat, V. 2009. In-vitro plant regeneration through somatic embryogenesis and direct shoot organogenesis in Pennisetum glaucum (L). R. Br. InVitro Cell Dev. Biol.-Plant, 45: 145 154.

Jain, S., Varshney, A. and Kothari, S.L. 2001. Embryogenic callus induction and efficient plant regeneration in Proso millet. Cereal Res. Communications, 29(3/4): 313-320.

Kavikishor, P.B., A.M. Rao, A.C. Dhar and Naidu, K.R. 1992. Plant regeneration in tissue culture of some millet. Indian $J$. Expt. Biol., 30: 729-733.

Kambale, M.S., B.L. Dhonukse, N.V. Kashid and Shirpurkar, G.N. 2004. Plant regeneration through somatic embryogenesis from germinated seed and coleoptile cultures of finger millet. Annals of Agri. Res., 25(2): 278-282.

Kaume, R.N. 2006. Panicum miliaceum L. In: Brink, M. and Belay, G. (Editors). PROTA 1: Cereals and pulses/Cereal's legumes secs [CD-Rom] PROTA, Wageningen, Netherlands

Larkin, P.J. and Scowcroft, W.R. 1981. Somaclonal variation a noval source of variability from cell cultures for plant improvement. Theo. App. Genet., 60: 197-214.

Masteller and Holden. 1970. The growth and organ formation from callus tissue of sorghum. Plant Physiol., 45: 362-364.

Mohanty, B.D., S. Gupta and Ghosh, P.O. 1985. Callus initiation and plantlet regeneration in Ragi (Eleusine coracana). Plant cell Tissue and Organ Culture, 5: 147-150.

Kuar, P. and Kothari, S.L. 2004. In-vitro culture of kodo millet influence of 2, 4$\mathrm{D}$ and Picloram in combination with kinetin on callus initiation and regeneration. Plant cell Tissue and Organ Culture, 71: 73-79.

Patil, S.M., S.V. Sawardekar, S.G. Bhave, S.S. Sawant, N.D. Jambhale and Gokhale, N.B. 2009. Development of somaclones and their genetic diversity analysis through RAPD in Finger millet (Eleusine coracana L. Gaertn.) Indian J. Genet., 69(2): 132-139.

\section{How to cite this article:}

Bankar Ashish Haridas and Gadakh Santosh Ashok. 2017. Standardization of in-vitro Callus Induction and Regeneration Protocol for Mature Embryo of Proso Millet (Panicum miliaceum L.). Int.J.Curr.Microbiol.App.Sci. 6(4): 2153-2163. doi: https://doi.org/10.20546/ijcmas.2017.604.253 